Acta Universitatis Nicolai Copernici • Pedagogika XXXVII/1/2019

Nauki Humanistyczno-Społeczne • Zeszyt 447

DOI: http://dx.doi.org/10.12775/AUNC_PED.2019.005

\author{
Kamilla Frejusz \\ Pontifical Faculty of Theology in Warsaw \\ Collegium Bobolanum \\ ORCID: 0000-0001-7620-6599
}

\title{
BibliCAL INSPIRATIONS OF JANUSZ TARnOWSKI's PERSONAL AND EXISTENTIAL PEDAGOGY
}

\begin{abstract}
:
The analyses undertaken in the article are aimed at highlighting the aspects of the personal and existential pedagogy Janusz Tarnowski is inspired by and make reference to biblical texts. The subject of the analysis was the approach to upbringing as a "dialogue and meeting" in selected scientific and popular science publications by Janusz Tarnowski. In his pedagogical thought we can find numerous inspirations taken from the Holy Bible. For him, the word of God contained in the Bible was the source from which he drew on the basis of which he justified such pedagogical issues as: education as a "dialogue and meeting", human dignity, and the prohibition of physical punishment. The discussion in the article leads to the conclusion that Janusz Tarnowski was not only inspired by the Bible but also encouraged his pupils to read it. In conversations with his pupils, he also gave testimony confirming the importance of the Holy Bible in both his life and his scientific work.
\end{abstract}

Keywords: personal and existential pedagogy, education, dialogue and meeting, Janusz Tarnowski. 


\section{STRESZCZENIE:}

Analizy podjęte w artykule mają na celu ukazanie w jakich aspektach stworzonej przez siebie pedagogiki personalno-egzystencjalnej Janusz Tarnowski inspiruje się tekstami biblijnymi i do nich nawiązuje. Przedmiotem analiz było ujęcie wychowania jako „dialog i spotkanie” w wybranych publikacjach naukowych oraz popularno-naukowych Janusza Tarnowskiego. W jego myśli pedagogicznej odnajdujemy liczne inspiracje zaczerpnięte z Pisma Świętego. Słowo Boże zawarte w Biblii stanowiło dla niego źródło, z którego czerpał i na podstawie którego uzasadniał takie kwestie pedagogiczne jak: ujęcie wychowania jako „dialog i spotkanie”, godność człowieka oraz zakaz stosowania kar fizycznych. Refleksja podjęta w artykule prowadzi do wniosku, że Janusz Tarnowski nie tylko inspirował się Biblią ale zachęcał swoich wychowanków do jej czytania. W rozmowach ze swoimi wychowankami dawał również świadectwo potwierdzające jak ważne miejsce w jego życiu i twórczości naukowej zajmuje Pismo Święte.

Słow a klucze: pedagogika personalno-egzystencjalna, wychowanie, dia$\log$ i spotkanie, Janusz Tarnowski.

Tanusz Tarnowski (1919-2012) is one of the most outstanding Polish pedagogues of the $20^{\text {th }}$ century. The theory created by Tarnowski is known as Christian existential pedagogy or personal and existential pedagogy. The specificity of Tarnowski's pedagogy is the original combination of Christian personalism with the existential philosophy of the theistic trend. From the existentialists of the theistic trend (K. Jaspers, M. Buber and G. Marcel), he derived and put in the centre of his pedagogical concept different existential categories: dialogue, authenticity, encounter, and commitment ${ }^{1}$. The categories of dialogue and encounter are the key elements of Christian personal and existential pedagogy. Although they are derived from existentialism, they are fully in line with the Christian concept of man and education. He found support and foundation for his views in the Bible and the teachings of the

1 J. Tarnowski, Jak wychowywać?, Warszawa 1993, pp. 89-90. 
Church, especially Vatican II. The Bible as a whole speaks about God's dialogue with people and calls for a dialogue and an encounter between man and God and between people themselves. Thus, accepting the categories of dialogue and encounter, and implicitly including the other categories of authenticity and commitment as the basic pedagogical categories, Tarnowski not only remains faithful to Christian inspirations but also reaches their deepest sources. Thus, the Bible is for him one of the most important inspirations in this subject. The categories analysed by Tarnowski not only accurately describe upbringing in terms of interpersonal relations in the horizontal dimension but also upbringing in the vertical dimension, i.e. religious, leading to a dialogue and an encounter between man and God.

Despite a common acceptance of the need for education, doctrinal assumptions, sources, standards, goals, methods, and educational methods remain the subject of intense discussion. Both in the substantive and historical order there are many positions and perspectives in the field of education ${ }^{2}$. One of the important voices in this matter is the Holy Bible, which is the basis and source of Christian education. The Church has always 'considered and regards these Scriptures as Holy Tradition, as the highest truth of faith, because they are inspired by God, recorded once and for all, they invariably convey the word of God himself, and in the statements of the Prophets and Apostles allow the voice of the Holy Spirit to resound. Therefore, all church teaching, as well as the Christian religion itself, must be fed and guided by Scripture' $^{3}$. Further, in Janusz Tarnowski's pedagogical thought, the Bible is an important and valuable source of inspiration. His conceptualisation of education as a "dialogue and meeting" draws from and bases its assumptions and foundations on biblical texts in which, as we read in the Dogmatic Constitution on Divine Revelation "Dei Verbum" of the

2 J. Bagrowicz, Wychowanie w świetle Biblii. In: Wychowanie chrześcijańskie. Między tradycją a współczesnością, ed. A. Rynio, Lublin 2007, p. 41.

3 Konstytucja dogmatyczna o Objawieniu Bożym "Dei Verbum" (KO), no. 21. In: Sobór Watykański II. Konstytucje, Dekrety, Deklaracje, Poznań 2002, pp. 350-362. 
Second Vatican Council, 'The Father who is in heaven meets graciously with his children and talks to them'4

Janusz Tarnowski often justifies the ideas of personal and existential pedagogy, and especially the approach to education as a "dialogue and meeting" with references to the Holy Bible. In his opinion, 'the Bible has many descriptions of God meeting with people. (...) The entire Bible can be called a great book of existential meetings' ${ }^{5}$. Speaking of dialogue, he refers primarily to 'the dialogue between God and man, which - as he writes - was most fully reflected in the incarnation of the Son of God, who through His death and resurrection made us children of God'6. In the pages of the New Testament he finds forms of dialogue which will later become the foundation of his pedagogical thought, which is developed in numerous books and articles: 'How many moments we find (...) moments of dialogue in the teaching of the Lord Jesus. The most classic is the one when He asks His disciples, "Who do people say the Son of Man is?" and He hears that "some say John the Baptist; others say Elijah; and still others, Jeremiah or one of the prophets". Later on, "Who do you say I am?" (Mt 16:13-15)"7. Biblical sources to which Tarnowski refers when discussing educational issues are, first and foremost, texts on anthropology, which he uses to establish his theory of upbringing as "dialogue and meeting". Speaking about biblical sources and foundations of Christian education, Bagrowicz also believes that 'these foundations are first set by biblical anthropology, which provides fundamental truths about the nature of man as the subject of upbringing. The Bible also offers interesting pedagogy: from its oldest texts to the pedagogy of the Gospel's. This key will also demonstrate the biblical sources of Janusz Tarnowski's pedagogical thought, ranging from the pedagogy included in the Old Testament to the New Testament texts referenced in the Dialogue Pedagogy.

4 Ibidem.

5 J. Tarnowski, Jak wychowywać?, op. cit., p. 142.

6 J. Tarnowski, Wychowanie do pokoju z Bogiem i ludźmi, Poznań 1981, p. 84.

7 J. Tarnowski, Jak wychowywać? W ogniu pytań, Ząbki 2003, p. 55.

8 J. Bagrowicz, Edukacja religijna współczesnej młodzieży. Źródła i cele, Toruń 2000, p. 111. 
The first biblical principle that Tarnowski refers to in his pedagogical thought is human dignity. The basis of the educational impact discovered in the Bible, especially in the Old Testament, is the science of human dignity. At the very beginning of Bible, in the description of the creation of man, we find a message about the source of this dignity'. Tarnowski refers to this truth many times, recalling that 'the Bible teaches that man was created in the image of God'10. In Tarnowski's teachings, this biblical truth about creating man in the image of God is the basis for the idea of upbringing as a "dialogue and meeting". Only 'being created in the image of God, can man enter into a dialogue with God'11. This theological and religious dimension of a human being is 'treated as the foundation of biblical parenetic pedagogy'12 and is the basis for Tarnowski's pedagogical reflection because it implies the inalienable right of every person to be brought up. Hence, a full presentation of man's personal dignity and his personal vocation to development through upbringing and perfection requires natural dignity to be taken into account alongside its supernatural destiny and origin ${ }^{13}$.

Being created in the image and likeness of God, man seeking his essence and trying to define his identity discovers his attachment to God in the very act of creation. This resemblance means that man is not able to comprehend himself or be embodied without God. He is the only creature that God wanted for himself and is only capable of finding the truth and the authenticity of his existence through an encounter with God. In this context, the biblical vision of man, based on God as Father and Creator, shows man's presence in who he is and who he should be ${ }^{14}$. Referring to human dignity in the context of upbringing as

9 J. Bagrowicz, Stawać się bardziej człowiekiem. Z podstaw edukacji religijnej, Toruń 2008, p. 17.

10 J. Tarnowski, Jak wychowywać?, op. cit., p. 82.

11 Léon-Dufour X.L., Słownik teologii biblijnej, Poznań 1994, p. 184.

12 W. Cichosz, Biblijne wychowanie parenetyczne: od pedagogiki do pedagogii, „Studia Katechetyczne” 8 (2012), p. 248.

13 B. Adamczyk, Model pedagogii Jezusa w przekazie biblijnym, Kraków 2008, p. 66.

14 S. Chrobak, Inspiracja chrześcijańska $w$ wychowaniu $w$ kontekście listu apostolskiego Jana Pawła II „Nuovo millennio ineunte”. In: Przemiany edukacyjne w Pol- 
a "dialogue and meeting", Janusz Tarnowski emphasises the specificity of the creation of man. He says, 'God creates man "in his own image" (Gen 1:27), so unlike the whole world. The difference lies not only in the fact that man is given the order to rule over the world like God (Gen 1:28), but he is endowed with freedom'15. What is more, creating man in the image and likeness of God does not exclude his freedom, including the possibility of committing sins ${ }^{16}$. The Holy Scripture teaches that man 'set himself against God and sought to attain his goal apart from God'17, and consequently he is a deeply conflicting being both socially and mentally. According to the Dialogue Pedagogy, this conflict 'has its final and deepest source in disagreement with God. (...) Rejection of God destroys both the attitude to the final goal and the internal order of man, as well as attitude to other people and all created things' ${ }^{18}$.

However, the fact that God is rejected does not mean that man ceases to participate in the image and likeness mentioned in the book of Genesis. The redemption of man by Christ, 'this shocking mystery of love, in which the mystery of creation is repeated again and again - is in its deepest core the exculpation of man'19. This is why in Christ we find justification for the dignity of the redeemed man and, therefore, human dignity assumes the Christocentric dimension ${ }^{20}$. Referring to numerous fragments of the New Testament, Janusz Tarnowski recalls this truth in the following words: "The mystery of man is truly explained in the mystery of the Incarnate Word. (...) Therefore, the mystery of suffering and death overwhelming us outside His Gospel, is clarified through Christ. Christ is risen, trampling over death by death,

sce i na świecie a modele wychowania, ed. W. Korzeniowska, Kraków 2001, p. 145.

15 J. Tarnowski, Problem chrześcijańskiej pedagogiki egzystencjalnej, Warszawa 1982, p. 231.

16 J. Gnilka, Teologia Nowego Testamentu, Kraków 2002, p. 46.

17 J. Tarnowski, Jak wychowywać?, op. cit., p. 82.

18 J. Tarnowski, Problem chrześcijańskiej pedagogiki egzystencjalnej, op. cit., p. 49.

19 J. Bagrowicz, Stawać się bardziej człowiekiem. Z podstaw edukacji religijnej, op. cit., p. 54.

20 Ibidem, p. 55. 
He gives us life so that we, as sons in the Son, would cry in the Spirit: Abba Father! (Rom 8:15; Gal 4: 6; Jn 1, 12 and $1 \mathrm{~J} 3$, 1) ${ }^{21}$. These words exemplify God's economy of salvation realised by Jesus Christ. At the beginning of the history of creation, man enters into sin, dragging all creation into it. By God's will, a perfect new man comes to earth, an immaculate image of the invisible God; he repairs the sin-disturbed order and restores God's image to man. Consequently, according to Barbara Adamczyk, it would be incorrect to say that the history of salvation, and indeed God's pedagogy for man, ended with the last word of the Old Testament. The purpose of the pedagogy of the Old Testament was above all to prepare the coming to earth of Jesus Christ, the Redeemer of all people ${ }^{22}$. This is why 'all ideas relevant to Christian education fall within Christocentrism as a principle ordering religious teaching and upbringing'23. The most important ideas for Tarnowski's pedagogical thought also revolve around the Christocentric moment, and thus the life and religious attitude of the children in his care are centred around the person of Jesus Christ ${ }^{24}$.

The biblical concept of man is the basis and justification of Janusz Tarnowski's Christian existential pedagogy. In his opinion, the most important features of the existential vision of man, which include freedom, individuality, complete separation of man's position in the world, the pursuit of authenticity, and the tragedy of existence, find their source in the Bible. He argues that 'opposing existentialism to the process of deantropomorphisation of man (carried out by both idealism and positivism), in the name of a specifically privileged human existence, has a firm foundation in the Holy Scripture, where man shaped in the image of God is the peak of all creation (Gen 1: 27) ${ }^{25}$. Anoth-

21 J. Tarnowski, Problem chrześcijańskiej pedagogiki egzystencjalnej, op. cit., p. 50 .

22 B. Adamczyk, Model pedagogii Jezusa w przekazie biblijnym, op. cit., p. 95.

23 J. Bagrowicz, Edukacja religijna wspótczesnej młodzieży. Źródła i cele, op. cit., p. 134.

24 J. Tarnowski, Próby dialogu z młodymi. Prekatecheza egzystencjalna, Katowice 1983, pp. 329-330.

25 J. Tarnowski, Problem chrześcijańskiej pedagogiki egzystencjalnej, op. cit., p. 167. 
er aspect of the existential concept of man, which is his individuality, 'striving to free himself from the hegemony of the crowd and find himself by adopting an authentic attitude, seems to be in the most compatible with the Christian spirit ${ }^{26}$. The characteristic of existentialism, the tragedy of human existence, having its final and deepest source in disagreement with God $^{27}$, is similarly reflected in the Bible. Thus, Tarnowski justifies the presence of elements of existentialism as a result of their compliance with biblical texts at the very basic level of pedagogical thought. The basis of human dignity, which is the foundation of God's educational interactions, is also the calling of man to cooperate with the Creator in further improvement of the world ${ }^{28}$. Indeed, in the second story about the creation of man, God asserts that man must be a contributor in the work of improving the world ${ }^{29}$. This aspect finds its application in Janusz Tarnowski's pedagogical thought, especially in the context of education for commitment, which is the result of an authentic dialogue focused on meeting between God and people ${ }^{30}$. When interpreting human activity in the light of Revelation, he refers to the biblical source; because man, created in the image of God, was given the task of ruling the world, 'his efforts to possess the land, both extraordinary and casual, correspond to God's intentions because they develop the work of the Creator'31. For the Dialogue Pedagogy, the pedagogical conclusion of this analysis is the necessity of upbringing in full human culture ${ }^{32}$.

Through biblical texts relating to children, Janusz Tarnowski stresses the dignity of a child. In one interview, he asserts that 'above all God invites children to dialogue. He entrusts to them the future of the wait-

\footnotetext{
26 Ibidem, p. 168.

27 Ibidem, p. 49.

28 J. Bagrowicz, Ideał wychowawczy Starego Przymierza (cz. 1). Pedagogia przymierza $w$ Pięcioksięgu. In: Pedagogika katolicka. Zagadnienia wybrane, ed. A. Rynio, Stalowa Wola 1999, p. 145.

29 B. Adamczyk, Model pedagogii Jezusa w przekazie biblijnym, op. cit., p. 69.

30 J. Tarnowski, Jak wychowywać?, op. cit., p. 177.

31 J. Tarnowski, Problem chrześcijańskiej pedagogiki egzystencjalnej, op. cit.,

32 Ibidem, p. 59.
} p. 57. 
ing adults. It is little Samuel who is chosen by him for this purpose, not the priest Heli, Samuel's protector (1 Sam 3,1-18)'33. There are also many instances in Tarnowski's books and articles where biblical statements testifying to the dignity of a child in the eyes of God are emphasised: 'Here, on the example of little Samuel, we see that children are invited to a dialogue with God who reveals to them the fate of adults awaiting (1 Sam 3:1-18), the mouths of children and babies, in spite of God's opponents, give Him special glory (Ps 8:3), and the Book of Job states, "Great age does not give wisdom, nor seniority fair judgement" (Job 32:9)'34. In the Old Testament we have many texts depicting a child as a gift of God, which, according to Bagrowicz, has its source in the book of Genesis, where procreation from the very beginning of humanity was gifted with the special blessing of God himself. Therefore, there is no fear of a child in the Old Testament. A new-born baby was received gratefully as a manifestation of a special blessing from God; it was seen as a gift of God, who thus joins human life ${ }^{35}$.

Janusz Tarnowski also references the Bible while mentioning the dignity of a child in the context of the Church, which in his opinion is 'called (...) to reveal and present the teaching of Christ who put a child in the very center of the Kingdom of God, saying, "Let the little children alone, and do not stop them from coming to me; for it is to such as these that the kingdom of Heaven belongs" (Mt 19:14; Lk 18:16; Mk 10:14) ${ }^{36}$. Moreover, Jesus himself defines the attitude of a child as a prerequisite for entering the kingdom of God: "In truth I tell you, anyone who does not welcome the kingdom of God like a little child will never enter it" (Mk 10:15). These words, according to the revolutionary words of the Dialogue Pedagogy, prove that Jesus sees in the attitude of a child the ideal that adults are to strive for ${ }^{37}$. The point here is to take the Kingdom like a child (Mk 10:15), to accept it with all simplicity as a gift from the Father, instead of demanding it as something

\footnotetext{
33 J. Tarnowski, Jak wychowywać? W ogniu pytań, op. cit., p. 103.

34 J. Tarnowski, Jak wychowywać?, op. cit., p. 18.

35 J. Bagrowicz, Wychowanie w świetle Biblii, op. cit., p. 53-54.

36 J. Tarnowski, Jak wychowywać?, op. cit., p. 21.

37 J. Tarnowski, Jak wychowywać? W ogniu pytań, op. cit., p. 105.
} 
due. '(...) The secret of true greatness lies in this to become like a child (...) and this is true humility, without which one cannot become a child of the heavenly Father'38. This attitude also demonstrates Tarnowski's belief that 'Jesus Christ - probably to a great surprise of his listeners - puts children above adults, whom he warns that "anyone who is the downfall of one of these little ones who have faith in me would be better drowned in the depths of the sea with a great millstone round his neck," they will be severely punished (Mt 18:6-11) ${ }^{39}$.

Numerous references to the Bible can also be found in Tarnowski's reflection on the infliction of corporal punishment to children. Referring to the article by sociologist Robert Toporkiewicz, in which we find an apology for corporal punishment based on selected biblical texts, he undertakes a broad discussion on the subject and specific fragments of the Holy Bible. In an article entitled 'Model of the Christian family', the aforementioned sociologist claims that the Bible contains many texts emphasising the need to apply punishments for proper upbringing. Citing the Book of Proverbs, he lists the following proofs: 'whoever fails to use the stick hates his child' (Prov 13:24), 'correct your child, and he will give you peace of mind; he will delight your soul' (Prov. 29:17), and 'the stick and the reprimand bestow wisdom, a young man left to himself brings shame on his mother' (Prov 29:15), as well as one from the Book of Sirach: 'Pamper your child and he will terrorise you (...), while he is young, do not allow him his freedom and do not wink at his mistakes. Bend his neck in youth, bruise his ribs while he is a child, or else he will grow stubborn and disobedient, and hurt you very deeply' (Sir 30:9:11-12). According to Toporkiewicz, the use of punishments in the Bible is recommended from the moment when the child can understand their meaning, i.e. from the earliest period of life. Moreover, he believes that the cardinal mistake is to punish only with a slap; this is because the child should feel pain so that in the future he will try to avoid it ${ }^{40}$.

38 Léon-Dufour X., Słownik teologii biblijnej, op. cit., p. 243.

39 J. Tarnowski, Jak wychowywać?, op. cit., p. 18.

40 R. Toporkiewicz, Model rodziny chrześcijańskiej, "Odpowiedzialność i czyn", no. 1 (1988), p. 23, 29. 
In order to better understand the argumentation of Toporkiewicz, the Dialogue Pedagogy cites fragments of his statements regarding bible passages on the use of corporal punishment. As if provocatively, he quotes additional fragments of the Old Testament, including Deuteronomy:

'If a man has a stubborn and rebellious son who will not listen to the voice either of his father or of his mother and, even when they punish him, still will not pay attention to them, his father and mother must take hold of him and bring him out to the elders of his town at the gate of that place. To the elders of his town, they will say, "This son of ours is stubborn and rebellious and will not listen to us; he is a wastrel and a drunkard." All his fellow-citizens must then stone him to death. You must banish this evil from among you. All Israel, hearing of this, will be afraid.' (Deut 21:18-21)

Trying to respond to the words quoted in one of the interviews that 'it seems that if I listen to the Bible, I have to beat the children - [Tarnowski answers] - it may seem so after reading these fragments. I emphasize - with these. We forget then all the remaining content of the Bible. This is a pars pro toto error (part of the whole) ${ }^{241}$.

Despite the statements given above, he does not deny that the Hebrew Bible does not justify the use of corporal punishment, the intention of which is to give wisdom and results from responsibility and love for the child. However, as Janusz Tarnowski emphasises, when reading the Old Testament carefully it is apparent that, in fact, the Mosaic Law limits the arbitrariness of parents who in ancient times had unlimited rights in relation to their children. In his opinion, Toporkiewicz manipulated, perhaps despite his will, the biblical texts. He chose out of many only those which proved his thesis, omitting one crucial stage in the interpretation of the Bible: taking into account the socio-cultural context in which individual texts were created. The Dialogue Pedagogy points to an error in interpretations of the Bible - the 'trap of anachronism' which consists of disregarding the different socio-cultural conditions of a given era. This is why, not only in his opinion, we are not demanding

41 J. Tarnowski, Jak wychowywać? W ogniu pytań, op. cit., p. 103. 
today (referring to Saint Paul) that every woman should wear a head covering during prayer (1 Cor 11:5) ${ }^{42}$. Janusz Tarnowski calls this error fundamentalism, i.e. 'not taking into account the human condition of the Bible, which was created thousands of years ago in specific economic, political and social situations. Knowing and understanding the contemporary way of thinking and seeing reality, so different from the modern one, is necessary for the correct understanding of many fragments of the Holy Scripture ${ }^{43}$. He believes that when quoting texts about the parents' physical violence against a child, one should also cite other biblical statements testifying to the child's great dignity and advocacy; Tarnowski does this as he also mentions Old Testament biblical texts which highlight the importance of a child in God's eyes, already cited in of this work on the subject of child dignity in the Bible ${ }^{44}$.

Although the subject of applying corporal punishment to a child, justified by the teaching of the Bible, is visible in many statements by Janusz Tarnowski ${ }^{45}$, his polemic was not always well understood. Numerous references to Toporkiewicz's text are effectively attributed to Tarnowski himself in an article by Ewa Jarosz and Cezary Kurkowski entitled 'The rod and discipline gives wisdom... On the social myth of the usefulness of beating in education ${ }^{26}$. These authors write that in Christian medieval Europe, the beating of children was argued, among others, by a biblical message. The pages of this Holy Book contain descriptions that were interpreted as incentives for physical punishment of children (Tarnowski 2001). The most distinctive set of verses in the Bible in this respect is the Book of Proverbs ${ }^{27}$.

Janusz Tarnowski did not hide that the family model presented by Toporkiewicz questions its Christian sketch. However, his work also re-

42 Ibidem, pp. 106-107.

43 J. Tarnowski, Rozmowy o wierze $i \dot{z} y c i u$, Katowice 1989, p. 173.

44 J. Tarnowski, Jak wychowywać?, op. cit., pp. 17-18.

45 J. Tarnowski, Kara cielesna w świetle Biblii. In: Bici bija, ed. J. Bińczycka, Warszawa 2001, pp. 34-43.

${ }^{46}$ E. Jarosz, C. Kurkowski, Rózga i karcenie udziela mądrości... O społecznym micie przydatności bicia $w$ wychowaniu, "Problemy Wczesnej Edukacji", no. 2 (2016), pp. 45-65.

47 Ibidem, p. 46. 
calls numerous events in the light of which the use of corporal punishment is rightly attributed to Christian communities. Examples include his discussion of the protest against the prohibition of corporal punishment in Great Britain, organised by forty Christian schools, justifying corporal punishment as a Judeo-Christian legacy, and the results of an American association report showing that in thirteen states in the south of the USA (constituting the so-called Bible belt - inhabited mainly by Methodist Christians literally interpreting the Holy Scriptures) there was still a conviction about the importance of corporal punishment in the pedagogical process ${ }^{48}$. Szymon Wójcik also refers to these words, noting that 'in some environments, traditional patterns of education with the use of violence, "sanctified" by centuries-old tradition, are still promoted. The recent publication of numerous books (mostly American, created in fundamental religious communities) caused a storm among children's rights activists and in the media as these books justified the use of physical punishment in raising children religiously e.g. through selected quotes from the Old Testament ${ }^{24}$. However, unlike Jarosz and Kurkowski, he emphasises that such "biblical" pedagogy is currently opposed by numerous Catholic clergy, warning against literal readings of the Old Testament without an understanding of the completely different cultural context. Wójcik also includes Janusz Tarnowski among these pedagogues ${ }^{50}$.

In the context of the use of corporal punishment in education the Dialogue Pedagogy most often recalls the teaching of Christ, who did not allow children to be humiliated: 'See that you never despise any of these little ones, for I tell you that their angels in heaven are continually in the presence of my Father in heaven' (Mt 18:10). At the same time, Tarnowski sees that Jesus' disciples found it difficult to free themselves from a sense of superiority to children. In his opinion, the event described in one of the Gospels is eloquent in this context, as when Jesus saw the reaction of his disciples towards the children he said "Let

48 J. Tarnowski, Kara cielesna w świetle Biblii, op. cit., pp. 35-36.

49 S. Wójcik, Przemoc fizyczna wobec dzieci, "Dziecko krzywdzone", no. 2 (2012), p. 21.

50 Ibidem. 
the little children come to me; do not stop them; for it is to such as these that the kingdom of God belongs. In truth I tell you, anyone who does not welcome the kingdom of God like a little child will never enter it." Then he embraced them, laid his hands on them and gave them his blessing. (Mk 10: 14-16) ${ }^{51}$. For Tarnowski, the recognition and acceptance of human dignity in a child is one of the most important conditions for educational dialogue. Justifying these words, he also recalls the statement of Jesus in which a childlike attitude is the ideal to which adults should strive: 'In truth I tell you, unless you change and become like little children you will never enter the kingdom of Heaven (Mt 18:3) ${ }^{52}$.

In Janusz Tarnowski's personal and existential pedagogy we find numerous references and inspirations drawn from the Holy Bible. For him, the word of God contained in the Bible was the source from which he drew and on the basis of which he justified such pedagogical issues as upbringing as a "dialogue and meeting", human dignity, or a prohibition of physical punishment. He repeatedly encouraged his pupils to read the Bible, regretting that 'he knows and reads the Bible too little, and yet it constantly shows that it is God who guides man throughout his life. The Bible contains the word of God, current and for today. When a man does not have this belief, then only dead formulas remain and counting only on himself ${ }^{53}$. In his conversations with his pupils, he gave testimony confirming how important the Bible is in his life and scientific work. He writes: 'There are however people - I belong to them - who read the Gospel, the Bible often, daily. They know some biblical sentences by heart. And what turns out? The Word of God is so deep and beautiful that you return to it as if you were eating bread, which we eat every day and we do not get bored with it. Someone said that isn't wasn't until the 40th or 50th time, reading or listening to some God's thought, that we begin to understand. And even more important - apply it in everyday life. Because the words of God are the

51 J. Tarnowski, Jak wychowywać? W ogniu pytań, op. cit., pp. 104-105.

52 J. Tarnowski, Wychowanie do pokoju z Bogiem i ludźmi, op. cit., p. 53.

53 J. Tarnowski, Jak wychowywać? W ogniu pytań, op. cit., p. 293. 
words of life"54. Indeed, these "words of life" can regularly be found in his pedagogical thought, which is so full of existentialism and so close to the life of his pupils. These words are also a valuable source of his pedagogical reflections and deliberations.

\section{References}

All Bible translations are from the New Jerusalem Bible standard edition. Darton: Longman and Todd and Les Editions du Cerf, 1985.

Adamczyk B., Model pedagogii Jezusa w przekazie biblijnym, Kraków: Wydawnictwo WAM, 2008.

Bagrowicz J., Edukacja religijna wspótczesnej młodzieży. Źródła i cele, Toruń: Wydawnictwo Uniwersytetu Mikołaja Kopernika, 2000.

Bagrowicz J., Ideał wychowawczy Starego Przymierza (cz. 1). Pedagogia przymierza $w$ Pięcioksięgu. In: Pedagogika katolicka. Zagadnienia wybrane, ed. A. Rynio, 143-162. Stalowa Wola: Oficyna Wydawnicza WN KUL, 1999.

Bagrowicz J., Stawać się bardziej człowiekiem. Z podstaw edukacji religijnej, Toruń: Wydawnictwo Naukowe Uniwersytetu Mikołaja Kopernika, 2008.

Bagrowicz J., Wychowanie w świetle Biblii. In: Wychowanie chrześcijańskie. Między tradycją a współczesnością, ed. A. Rynio, 39-60, Lublin: Wydawnictwo KUL, 2007.

Chrobak S., Inspiracja chrześcijańska $w$ wychowaniu $w$ kontekście listu apostolskiego Jana Pawta II „Nuovo millennio ineunte”. In: Przemiany edukacyjne $w$ Polsce i na świecie a modele wychowania, ed. W. Korzeniowska, 141-151. Kraków: Oficyna Wydawnicza Impuls, 2001.

Cichosz W., „Biblijne wychowanie parenetyczne: od pedagogiki do pedagogii", Studia Katechetyczne 8(2012): 243-253.

Gnilka J., Teologia Nowego Testamentu, Kraków: Wydawnictwo „M”, 2002.

Jarosz E., Kurkowski C., „Rózga i karcenie udziela mądrości... O społecznym micie przydatności bicia w wychowaniu", Problemy Wczesnej Edukacji 2 (2016): 45-65.

54 J. Tarnowski, Jak wychowywać? Uczyć się od wychowanków (przyjaciót), Kraków 2005, p. 155. 
Léon-Dufour X., Słownik teologii biblijnej, Poznań: Pallottinum, 1994.

Sobór Watykański II, Konstytucja dogmatyczna o Objawieniu Bożym „Dei Verbum” (KO). In: Sobór Watykański II. Konstytucje, Dekrety, Deklaracje, 350-362. Poznań: Pallottinum, 2002.

Tarnowski J., Jak wychowywać? Uczyć się od wychowanków (przyjaciót), Kraków: Oficyna Wydawnicza „Impuls”, 2005.

Tarnowski J., Jak wychowywać?, Warszawa: Wydawnictwo Akademii Teologii Katolickiej, 1993.

Tarnowski J., Kara cielesna w świetle Biblii. in: Bici bija, ed. J. Bińczycka, 34-43, Warszawa: Wyższa Szkoła Pedagogiczna Związku Nauczycielstwa Polskiego, Wydawnictwo Akademickie „Żak”, 2001.

Tarnowski J., Problem chrześcijańskiej pedagogiki egzystencjalnej, Warszawa: Akademia Teologii Katolickiej, 1982.

Tarnowski J., Próby dialogu z młodymi. Prekatecheza egzystencjalna, Katowice: Księgarnia św. Jacka, 1983.

Tarnowski J., Rozmowy o wierze i życiu, Katowice: Księgarnia Św. Jacka, 1989.

Tarnowski J., Wychowanie do pokoju z Bogiem i ludźmi, Poznań: Księgarnia św. Wojciecha, 1981.

Tarnowski J., Jak wychowywać? W ogniu pytań, Ząbki: Wydawnictwo Apostolicum, 2003.

Toporkiewicz R., „Model rodziny chrześcijańskiej”, Odpowiedzialność i czyn 1 (1988): 23-29.

Wójcik Sz., „Przemoc fizyczna wobec dzieci”, Dziecko krzywdzone 2 (2012): 7-27. 